\title{
RESEARCH OF MICROBIOLOGICAL INDICATORS OF QUALITY OF SURFACE WATERS OF NATURAL ENVIRONMENTAL TERRITORIES OF THE DANUBE BASIN
}

\author{
Andrew Masikevych \\ Department of Hygiene and Ecology \\ Bucovinian State Medical University \\ 2 Teatralna sq., Chernivtsi, Ukraine, 58000 \\ masikevich.a@gmail.com

\section{Mikhail Kolotylo} \\ Department of Ecology and Law of Chernivtsi Faculty \\ National Technical University "Kharkiv Polytechnic Institute" \\ 2 Kyrpychova str., Kharkiv, Ukraine, 61002 \\ vyzhpark@ukrpost.ua \\ Valery Yaremchuk \\ Department of Ecology and Law of Chernivtsi Faculty \\ National Technical University "Kharkiv Polytechnic Institute" \\ 2 Kyrpychova str., Kharkiv, Ukraine, 61002 \\ vyzhpark@ukrpost.ua \\ Yurij Masikevych \\ Department of Hygiene and Ecology \\ Bucovinian State Medical University \\ 2 Teatralna sq., Chernivtsi, Ukraine, 58000 \\ yumasik@meta.ua \\ Valentyn Myslytsky \\ Department of Pathological Physiology \\ Bucovinian State Medical University \\ 2 Teatralna sq., Chernivtsi, Ukraine, 58000 \\ myslytsky@gmail.com

\section{Ivan Burdeniuk} \\ PhD, Assistant \\ Department of microbiology and virucology \\ Bucovinian State Medical University \\ 2 Teatralna sq., Chernivtsi, Ukraine, 58000 \\ microbiology@bsmu.edu.ua

\section{Konstantin Dombrovskyi} \\ Department of General and Applied Ecology and Zoology \\ Zaporizhzhya National University \\ 66 Zhukovsky str., Zaporizhzhya, Ukraine, 69600 \\ dombrov1717@ukr.net
}

\footnotetext{
Abstract

A comparative analysis of the sanitary and ecological state of surface watercourses in the upper part of the Danube basin (on the territory of Ukraine) was carried out according to microbiological indicators. Similar hygienic studies were previously conducted in the middle and lower Danube in Austria, Slovakia, Hungary and Romania. In Ukraine, the river network of the Danube River basin was not studied by microbiological indicators.
} 
The object of research is the watercourses on the territory of various zones of the nature protection object, which are different in function. This approach makes it possible to use hygienic indicators of water in protected areas of nature conservation areas as a reference for conducting background monitoring.

The original design of the treatment plant based on the use of "Viya" fibrous carrier and "paste" technical structure is proposed. It was established that as the transition from the reserve to the economic zone occurs, the nitrate content in the water increases, the BOD increases in water, and the dissolved oxygen in the water decreases for all the watercourses studied. Significant differences in microbiological indices of watercourses of various functional zones of the protected object have been revealed.

The possibility of using the sanitary-microbiological indicators of the river network as a reliable rapid test for assessing the state of environmental safety of nature conservation areas is shown.

Keywords: nature protection areas, functional zones, surface waters, Danube basin, sanitary-microbiological indicators.

\section{Introduction}

Sanitary-microbiological indicators are successfully used as indicators of environmental pollution: water, air, soil [1-3], as well as to monitor the status of ecosystems, forecasting and modeling of development. In connection with the rapid reaction to environmental changes, bacteria proved to be ideal markers of microbial contamination of surface waters [4]. This approach is especially valuable for protected areas. Protected areas serve as background sites for assessing the ecological status and changes in the environment. Studying their condition makes it possible to predict changes in the environment to a distant future.

The object of research is the sanitary and epidemiological indicators of the water network of the Siret River. This river enters the upper part of the Danube basin and forms the basis of the hydrological network of the protected nature reserve "Vyzhnytsia National Nature Park". The Danube is one of the most important rivers of Europe and the world and, simultaneously, according to a number of authors [4], is one of the most vulnerable aquatic ecosystems. For monitoring the water quality of the Danube River, the coastal countries currently use different approaches and methods of sanitary and ecological analysis, which does not allow the formation of a holistic picture of the state of the ecosystem of an important waterway in Europe. That is why the use of microbiological analysis as a universal approach for water quality monitoring by the coastal countries of the international river Danube is relevant at this time.

\section{Literature review and problem statement}

To date, there is a strong demand for monitoring water quality. Researches of scientists of the Institute of Hydrometeorology from Bratislava [5] suggest the use of autoregressive models for studying the impact of natural and technogenic changes on the quality of the Danube.

In terms of monitoring the water network, the assessment of the presence of pathogenic bacteria in water is of particular interest, according to the American School of Researchers at the University of California, Davis and Iowa State University. In particular, this concerns the problems associated with the use of indicator organisms for this purpose. This approach is the main problem of protecting human and animal health $[6,7]$.

The results obtained by Hungarian researchers [8] indicate that the bacteriological properties of water can be a specific indicator of fecal pollution and organic contamination. That is why, according to the authors, microbiological contamination by fecal (pathogenic) bacteria is considered to be the most important issues of surface water quality, and especially in the Danube basin. The accumulation index of E. coli is one of the specific indicators of fecal contamination of the aquatic environment, and can be used for express diagnostics of the aquatic environment.

An interesting experience is the assessment of the quality of the surrounding aquatic environment of the Kingdom of the Netherlands [11]. The national program for monitoring surface water in this country, in addition to hydrochemical indicators, including also hydrobiological monitoring (including epidemiological). In a number of EU countries (most of which have their own 
biological assessment of surface waters), bacteria, algae, invertebrate hydrobionts, phytoplankton are used as bioindicators $[12,13]$.

Researchers [9] have summarized existing methods of microbiological bioindication of the aquatic environment. It should be noted that the standards of the USSR in the field of protection of the hydrosphere operating in Ukraine do not take into account bacteriological indicators of water quality. This was, in all probability, the reason that data on the microbiological state of the upper part of the Danube basin (in the Ukrainian part: Tisza, Prut, Siret rivers) are practically absent.

Since water quality assessment is expensive [14], the development of rapid assessment methods remains an urgent problem. The introduction of this approach in many developed countries can reduce the cost of monitoring.

It should also be noted that the use of sanitary and microbiological indicators of the river network for assessing the status of protected sites, to date, is episodic [4, 10]. The question of assessing the sanitary and hygienic quality of surface waters of different purpose and status of functional zones of nature protection territories remains to be fully investigated.

The analysis of literature data confirms the need to use methods of sanitary-microbiological analysis of surface waters for assessing the ecological status of nature reserves and monitoring of aquatic ecosystems as a whole.

\section{The aim and objectives of research}

The aim of research is studying the epidemiological state of the surface waters of the river network of the Siret River (the upper part of the Danube basin, the Ukrainian territory) of various functional zones of the nature reserve object.

To achieve the aim, the following tasks are set:

- to determine the main sanitary and microbiological indicators (nitrite content, biological oxygen consumption, dissolved oxygen, coli-index, total microbial number), determine the quality of surface waters;

- to conduct a comparative analysis of sanitary and microbiological indicators, various in terms of the functional purpose of the zones, a nature reserve site;

- to study the possibility of using the proposed "biofilter", created on the basis of "Viya" artificial fibrous carrier and "paste" technical design, for assessing the quality of surface waters of various functional zones of a nature reserve site.

\section{Materials and methods for research of surface water quality indicators}

The watercourses have been studied: rivers Stebnyk, Sukhyi Strumok, Solonets entering the Ukrainian part of the Danube Basin. To assess the quality of the surface waters of the waterways of the Vyzhnytsia national nature park (NNP), Viya fibrous carrier (TU (995990)) was used. It made from a textured filament yarn (TU 6-06-C116-87, text 350) is described in [15].

Earlier $[15,16]$ it was established that a fibrous carrier of this type can be successfully used to construct "biofilters" for cleaning surface water. In particular, it was shown that the effectiveness of the "bioreactor" depends on the temperature, the concentration of microorganisms and that the accumulation of phytoplankton and heterotrophic microorganisms on carriers is most effective in the summer period (July-August). Using the approach described by the authors, a "biofilter" was mounted on the basis of special wooden structures - "paste", have long been used by local residents to saturate the streams with oxygen (Fig. 1). "Biofilter" is intended for adsorption on its surface of bacteria on hydrobionts.

The studies were carried out during the summer season 2016 and 2017. Sampling of water $\left(23-25^{\circ} \mathrm{C}\right)$ was carried out immediately before and after the "biofilters" from different functional zones of the waterways of the NNPs indicated in the scheme (Fig. 2), in accordance with the existing standard techniques. The choice of water sampling points was determined by their belonging to the functional zones of the protected object. The linking of the research region to the map of Europe is shown in Fig. 3. 


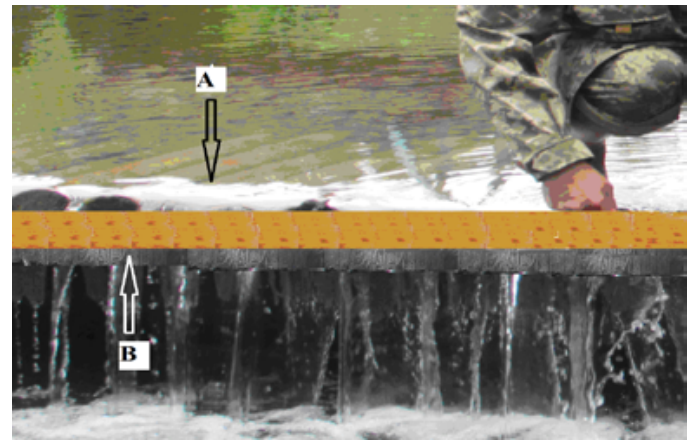

Fig. 1. When installing a cleaning structure using "Viya" fibrous carrier: A - a «paste» wooden structure; B - "Viya" fibrous carrier



Fig. 2. Map-scheme of functional zoning of Vyzhnytsia national nature park: sampling points: 1 - the upper part of the Stebnik riverbed, 2 - the upper part of the Sukhyi Strumok canal, 3 - the upper part of the Slavets riverbed, 4 - "OIKOS" recreational zone, 5 - "Myslyvskyi budynok" recreational zone, 6 - the lower part of the Stebnik riverbed, 7 - the lower part of the Sukhyi Strumok canal, 8 - the middle part of the Solonets riverbed 


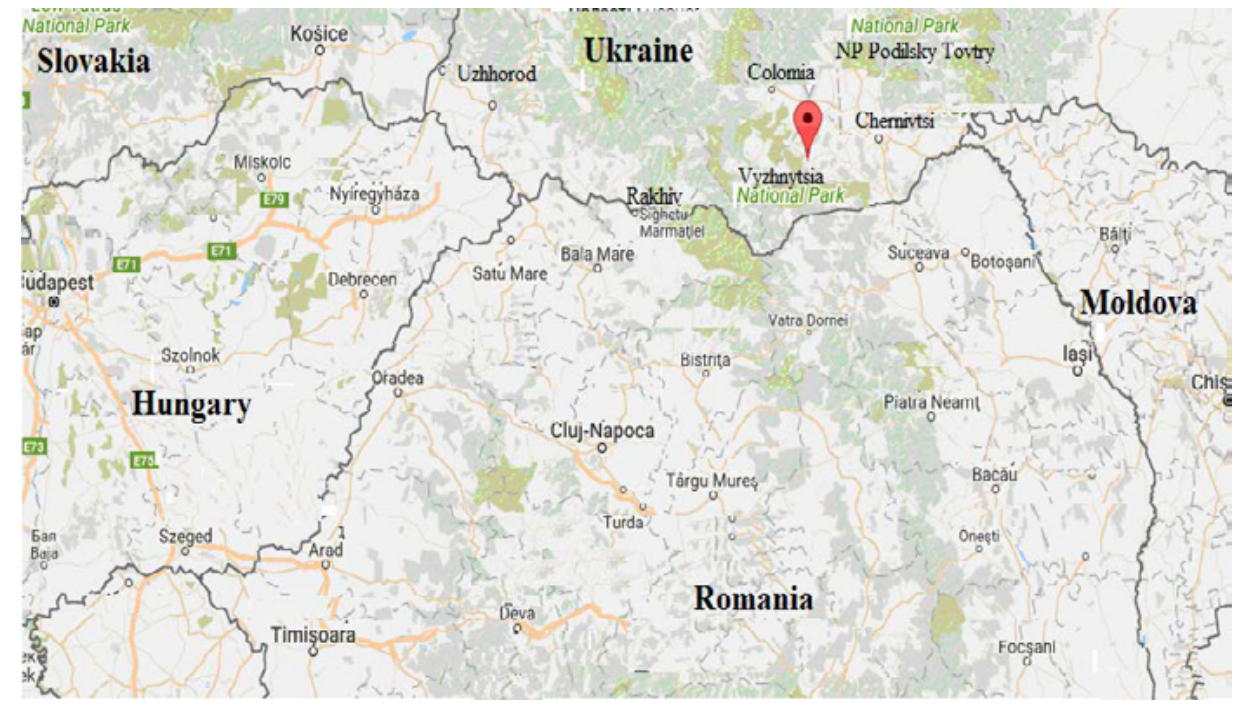

Fig. 3. Geographical location of the research area on the map of Europe

The investigated watercourses are a rather convenient model for studying the quality of surface waters of various functional zones of the nature reserve object, because they include three zones: a reserved zone in the upper part of the riverbed, a recreational zone in the middle of the riverbed and a recreational zone in the lower part.

The content of nitrates was determined in accordance with DSTU 40780-2001, biological oxygen consumption, dissolved oxygen, coli-index, total microbial number was determined by conventional methods in accordance with methodological guidelines [17].

The hydrobiological material (biocenosis of the periphyton overgrowth of the Viya" fibrous carrier) was selected in the second decade of August. The material was delivered to the laboratory in an open vessel. The infusoria, rotifers and turbolarium of the fouling biocenosis were studied in a living state under the Biola R-14 microscope, with an increase of 150-600 times. Other organisms (larvae of amphibiotic insects and nematodes) were fixed with $70^{\text {a }}$ ethanol and determined their species affiliation. The species were determined according to determinants and scientific works $[18,19]$. The statistical processing of the results was carried out using the computer program Excel.

\section{Research results of surface water quality of various functional areas of the Vyzhnytsia NNP}

The carried out researches have shown that there is an increase in the value of sanitary and microbiological indicators downstream along all these watercourses. Especially it concerned the increase in the amount of lactose-positive E. coli (E. coli) per 1 liter of water (coli-index). It should be noted that the E. coli is a sanitary indicator and indicates fecal contamination in this case of water bodies of the environment. Comparing the indices of coli-index in samples of river water of the protected zone and selected water samples in the economic zone, an increase in the coliform index was found to be 2 times on average (Table 1). At the same time, the total microbial number $(\mathrm{CFU} / \mathrm{ml}$ ) exceeded by 2-4 times the normative indicators adopted in the EU countries (Surface Water Directive: 75/440 EU) and amounted to 1500-1700 (for the protected zone), 2300-3500 (for the stationary zone recreation) and more than 5000 (for the economic zone).

Downstream of the watercourses, and the transition from the reserve to the economic zone, there is a growth in the water content of nitrates, an increase in the BOD index and a decrease in dissolved oxygen in the water. The obtained results indicate an increase in pollution of the river network by organic residues, in particular, they can be fecal connections of the economic zone where there are no existing treatment facilities.

The study of the qualitative species composition of organisms (periphyton) that inhabited the fibrous substrate showed bacteria, protozoa, fungi, algae, worms, crustaceans, bivalves and others to form fouling. 
The data are presented in Fig. 4 indicate that the "Viya" fibrous material is able to accumulate in considerable quantities the bacteria of the E. coli group (Fig. 4).

Table 1

The values of the main sanitary-microbiological indices of various functional zones of the Vyzhnytsia NNP*

\begin{tabular}{|c|c|c|c|c|c|}
\hline Sampling points & $\begin{array}{c}\mathrm{BOD}_{\text {tot }} \\
\left(\mathrm{mg} \mathrm{O}_{2} / \mathbf{d m}^{3}\right)\end{array}$ & $\begin{array}{l}\text { Dissolved oxygen } \\
\left(\mathrm{mg} \mathrm{O}_{2} / \mathbf{d m}^{3}\right)\end{array}$ & $\begin{array}{c}\text { Coli-index } \\
\left(\mathbf{d m}^{3}\right)\end{array}$ & $\begin{array}{c}\text { Microbial number } \\
(\mathrm{CFU} / \mathrm{ml})\end{array}$ & $\begin{array}{c}\text { Nitrogen } \\
\left(\mathbf{m g ~ N} / \mathbf{d m}^{3}\right)\end{array}$ \\
\hline \multicolumn{6}{|c|}{ protected area } \\
\hline 1 & $1,8 \pm 0,10$ & $7,5 \pm 0,55$ & $85 \pm 10,5$ & $1500 \pm 85,4$ & $0,01 \pm 0,001$ \\
\hline 2 & $2,3 \pm 0,12$ & $7,1 \pm 0,50$ & $80 \pm 8,0$ & $1700 \pm 90,2$ & $0,02 \pm 0,001$ \\
\hline 3 & $2,0 \pm 0,08$ & $8,0 \pm 0,70$ & $82 \pm 12,2$ & $1600 \pm 65,5$ & $0,02 \pm 0,002$ \\
\hline \multicolumn{6}{|c|}{ zone of stationary recreation } \\
\hline 4 & $5,1 \pm 0,30$ & $5,2 \pm 0,60$ & $90 \pm 11,5$ & $2300 \pm 92,5$ & $0,02 \pm 0,03$ \\
\hline 5 & $4,5 \pm 0,25$ & $6,0 \pm 0,55$ & $100 \pm 9,4$ & $3500 \pm 150,4$ & $0,05 \pm 0,004$ \\
\hline \multicolumn{6}{|c|}{ economic zone } \\
\hline 6 & $8,8 \pm 0,50$ & $4,2 \pm 0,20$ & $120 \pm 15,3$ & $5800 \pm 250,5$ & $0,15 \pm 0,02$ \\
\hline 7 & $9,2 \pm 0,45$ & $4,0 \pm 0,25$ & $105 \pm 12,5$ & $5200 \pm 280,3$ & $0,10 \pm 0,01$ \\
\hline 8 & $9,5 \pm 0,40$ & $3,8 \pm 0,20$ & $110 \pm 14,6$ & $5500 \pm 255,2$ & $0,14 \pm 0,02$ \\
\hline
\end{tabular}

Note: * the data are reliable for $p<0.05$; the name of the sampling points corresponds to the notation of Fig. 2

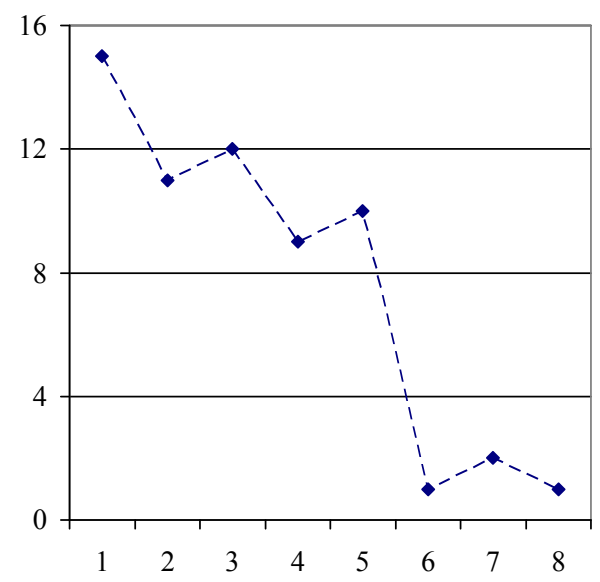

Fig. 4. The coefficient of accumulation of bacteria on fibrous carriers "Viya": the name of the sampling points corresponds to the notation in Fig. 2; coefficient of accumulation - the multiplicity of excess of content in comparison with the surrounding water environment.

As the data in Fig. 4 for sampling points 1, 2, 3, included in the NNP protected area is characterized by a high coefficient (from 11 to 14 times) of the accumulation of bacteria on fibrous carriers. In water samples taken in the zone of stationary recreation (points 4-5), this coefficient also has a sufficiently high index in the range of 9-10 units, that is, the carrier accumulates on its surface an order of more bacteria than the river water of the sampling points.

In the periphyton of the "Viya" fibrous carrier, 12 species and subspecies of hydrobionts were found. Most of these hydrobionts belong to amphibiotic insects ( 8 taxa). Rotifers and infusoria are represented by 2 taxa, respectively. Other systematic groups (ciliated worms, nematodes) were represented by one species, respectively. The species composition of the hydrobionts was supplemented with new species as the transition from the protected zone -5 species (points $1,2,3$ ) to the zone of stationary recreation -7 species (points 4,5 ) and the economic zone -12 species (points $6,7,8$ ). 


\section{Discussion of the research results of surface water quality of various functional zones of the Vyzhnytsia NNP}

Comparison of the obtained results (Table 1) with the normative indicators adopted in the EU countries (Surface Water Directive: 75/440 EU) give grounds to assert that the surface waters of the river network of the NNP reserve and recreational zone refer to the permissible level of pollution. At the same time, the river water of the economic zone does not meet the sanitary and hygienic requirements and refers to a moderate and high pollution degree. The use of water of this pollution degree, without proper cleaning, can lead to the appearance of a number of diseases in the population.

The conducted studies showed (Fig. 4) that in the protected zone and the zone of NNP stationary recreation, the maximum values of the accumulation coefficient of bacteria on fibrous carriers take place. This coefficient characterizes the multiplicity of exceeding the amount of E. coli group on a synthetic carrier in comparison with the surrounding aqueous medium. It is known that the presence of E. coli group in water indicates fecal contamination and, accordingly, the possible contamination of water by pathogenic microorganisms of the intestinal group (typhoid, paratyphoid, dysentery, etc.) [8]. However, the detection and isolation of pathogens is complicated by the low concentration of bacteria in surface waters, the high financial costs and the length of detection technology [23]. The use of natural adsorbents is well-established in this regard [24]. In order to overcome this methodological obstacle, "biofilter" based on a synthetic material such as "Viya" was used. It was mounted on special "paste» wooden structures. The data in Fig. 3 indicate that the use of the "biofilter" makes it possible to concentrate the E. coli group for their identification and possible destruction.

It is also shown that as the transition to the economic zone and the increase in the amount of organic pollution of waterways, there is a sharp increase in the magnitude of the coli-index and the microbial number (Table 1). At the same time, the accumulation coefficient of E. coli group on the "biofilter" is characterized by minimal indicators. This can be explained by the saturation of the absorption surface by microorganisms, and also by their partial incorporation into nutrient chains.

One of the proofs of this statement is an increase in the species composition of hydrobionts on the "biofilters" of the watercourses of the economic zone. Thus, representatives of rotifers, copepods (and other lithophilic species) prevailed in water samples collected in the protected zone (upper part of the current). At the same time, in the water of the economic zone, with the growth of organic detritus, the species composition of the fouling is replenished at the expense of detritophages, incl. nematodes, oligochaetes, dreissena and others.

Thus, a specific "biofilter" in the form of an artificially created microecosystem is formed downstream on fibrous carriers. In this microecosystem fibrous carrier serves as a kind of "home" for microorganisms, plant and invertebrate animal organisms, they are able to accumulate, which is the basis for cleaning reservoirs. In addition, some bacteria, in all probability, become an element of the feeding chain and serves as food for invertebrate hydrobionts. Thus, water reservoirs are cleaned in two stages: due to adsorption on synthetic carriers in the first stage and trophic chains on the second stage.

In general, in the estuary part of the tributaries of the Siret basin there is a significant contamination of surface waters (III-IV quality class), which is consistent with the results of studies [25], which showed that it is the Siret and Prut rivers that are significant factors in the pollution of the lower part of the Danube riverbed.

\section{Conclusions}

1. It is shown that as the transition from the protected to the economic zone occurs, the nitrate content in the water increases, the BOD index increases and the dissolved oxygen in the water decreases for all the investigated watercourses.

2. "Viya" fibrous carrier is capable of effective accumulation on the adsorbing surface of microorganisms of bacteria of the group of Escherichia coli and invertebrate hydrobionts for watercourses with insignificant content of organic pollutants. 
3. Significant differences in microbiological indices of watercourses of various functional zones of the protected object have been established. The total microbial number $(\mathrm{CFU} / \mathrm{ml})$ was 1500-1700 (for the protected zone), 2300-3500 (for the zone of stationary recreation) and more than 5000 (for the economic zone).

3. It is shown that during the growth of organic pollution of water bodies, especially in the economic zone of nature protection territories, a kind of "biofilters" - artificial microecosystems are formed on fibrous carriers.

4. The obtained results supplement the idea of the sanitary and ecological state of the Danube basin in its upper part on the territory of Ukraine. Pollution of the upper part of the Siret river basin ultimately determines the level of pollution of the lower part of the Danube riverbed, and actually affects the state of the ecosystem of this international waterway of Europe.

\section{References}

[1] Sumampouw, O. J., Risjani, Y. (2014). Bacteria as Indicators of Environmental Pollution: Review. International Journal of Ecosystem, 4 (6), 251-258.

[2] Ashbolt, N. J. (2015). Microbial Contamination of Drinking Water and Human Health from Community Water Systems. Current Environmental Health Reports, 2 (1), 95-106. doi: 10.1007/s40572014-0037-5

[3] Hermans, S. M., Buckley, H. L., Case, B. S., Curran-Cournane, F., Taylor, M., Lear, G. (2016). Bacteria as emerging indicators of soil condition. Applied and Environmental Microbiology, 83 (1). doi: 10.1128/aem.02826-16

[4] Pall, E., Niculae, M., Kiss, T., Sandru, C. D., Spinu, M. (2013). Human impact on the microbiological water quality of the rivers. Journal of Medical Microbiology, 62, 1635-1640. doi: 10.1099/ jmm.0.055749-0

[5] Pekarova, P., Onderka, M., Pekar, J., Roncak, P., Miklanek, P. (2009). Prediction of Water Quality in the Danube River Under extreme Hydrological and Temperature Conditions. Journal of Hydrology and Hydromechanics, 57 (1), 3-15. doi: 10.2478/v10098-009-0001-5

[6] Pandey, P. K., Kass, P. H., Soupir, M. L., Biswas, S., Singh, V. P. (2014). Contamination of water resources by pathogenic bacteria. AMB Express, 4 (1), 51. doi: 10.1186/s13568-014-0051-x

[7] Pandey, P. K., Soupir, M. L. (2013). Assessing the Impacts ofE. coliLaden Streambed Sediment onE. coliLoads over a Range of Flows and Sediment Characteristics. JAWRA Journal of the American Water Resources Association, 49 (6), 1261-1269. doi: 10.1111/jawr.12079

[8] Bayoumi Hamuda, H. E. A. F., Patko, I. (2012). Ecological monitoring of Danube water quality in Budapest region. American Journal of Environmental Sciences, 8 (3), 202-211. doi: 10.3844/ ajessp.2012.202.211

[9] Ryl's'kyi, O. F., Masikevych, Yu. G. (2012). Mikrobiolohichna bioindykatsiyi dovkillya zabrudnenoho vazhkymy metalamy ta inshymy ksenobiotykamy. Visnyk Zaporiz'koho natsional'noho universytetu, 3, 139-147.

[10] Mudrak, O. V. (2012). Zbalansovanyy rozvytok ekomerezhi Podillya: stan, problemy, perspektyvy. Vinnytsya, 914.

[11] Schets, F. M., van Wijnen, J. H., Schijven, J. F., Schoon, H., de Roda Husman, A. M. (2008). Monitoring of Waterborne Pathogens in Surface Waters in Amsterdam, The Netherlands, and the Potential Health Risk Associated with Exposure to Cryptosporidium and Giardia in These Waters. Applied and Environmental Microbiology, 74 (7), 2069-2078. doi: 10.1128/aem.01609-07

[12] Farcas, A. N., Curtean-Banaduc, A., Kifor, C. V. (2013). Ecological assessment as a first step in the evaluation of ecosystem services provided by lotic ecosystems. Management of Sustainable Development, 5 (2), 9-12. doi: 10.2478/msd-2013-0009

[13] Azzoni, R. (2015). Il controllo della qualita delle acque del fiume Adda mediante un metodo di analisi biocenotica. Boll. chim. Unione ital. lab. Prov., 31 (6), 293-305.

[14] Klochenko, P., Shevchenko, T., Barinova, S., Tarashchuk, O. (2014). Assessment of the ecological state of the Kiev Reservoir by the bioindication method. Oceanological and Hydrobiological Studies, 43 (3), 228-236. doi: 10.2478/s13545-014-0137-8 
[15] Gvozdyak, P. I. (2003). Za pryncypom biokonveyera. Biotexnologiya oxorony dovkillya. Visnyk NAN Ukrayiny, 3, 29-36.

[16] Masikevych, A., Masikevych, Yu., Myslytsky, V., Burdeniuk, I. (2016). Valuation hydroecological and sanitary-hygienic condition of the river network of Pokutsko-Bukovinisn Carpathians policy. Water Security. Mykolaiv: PMBSNU, Bristol: UWE, 308.

[17] Sanitarno-virusolohichnyy kontrol' vodnykh ob»yektiv: metod. vkazivky MV 10.2.1-1452007. Pro zatverdzhennya metodychnykh vkazivok «Sanitarno-virusolohichnyy kontrol' vodnykh ob»yektiv» (2007). Ministerstvo okhorony zdorovia Ukrayiny, No. 284. Dodatok 1. Available at: http:// www.moz.gov.ua/docfiles/8203_dodatok.rar Last accessed: 18. 01.2018

[18] Berger, H. (2008). Monograph of the Amphisiellidae and Trachelostylidae (Ciliophora, Hypotricha). Salzburg, 736. doi: 10.1007/978-1-4020-8917-6

[19] Kutikova, L. A., Starobogatov, Ya. I. (1977). Opredelitel presnovodnykh bespozvonochnykh Evropeyskoy chasti SSSR (plankton i bentos). Leningrad, 511.

[20] Barinova, S. (2017). On the Classification of Water Quality from an Ecological Point of View. International Journal of Environmental Sciences \& Natural Resources, 2 (2). doi: 10.19080/ ijesnr.2017.02.555581

[21] Odume, O. N.; Tutu, H. (Ed.) (2017). Ecosystem Approach to Managing Water Quality. Water Quality. doi: 10.5772/65707

[22] Directive 2000/60/EC of the European Parliament and of the Council of 23 October 2000 establishing a framework for Community action in the field of water policy (2000). Official Journal of the European Communities, 43, 72.

[23] Thompson, D. E., Rajal, V. B., De Batz, S., Wuertz, S. (2006). Detection of Salmonella spp. in water using magnetic capture hybridization combined with PCR or real-time PCR. Journal of Water and Health, 4, 67-75.

[24] Malyovanyi, M., Sakalova, G., Chornomaz, N., Nahurskyi, O. (2013). Some kinetic regularities of intracellular substance extracting. Chemistry and chemical technology, 7 (3), 198-208.

[25] Kirschner, A. K. T., Kavka, G. G., Velimirov, B., Mach, R. L., Sommer, R., Farnleitner, A. H. (2009). Microbiological water quality along the Danube River: Integrating data from two whole-river surveys and a transnational monitoring network. Water Research, 43 (15), 3673-3684. doi: 10.1016/j. watres.2009.05.034 